\title{
When I left, you did not ask me to stay
}

\section{The call of duty. By Steven Fischer}

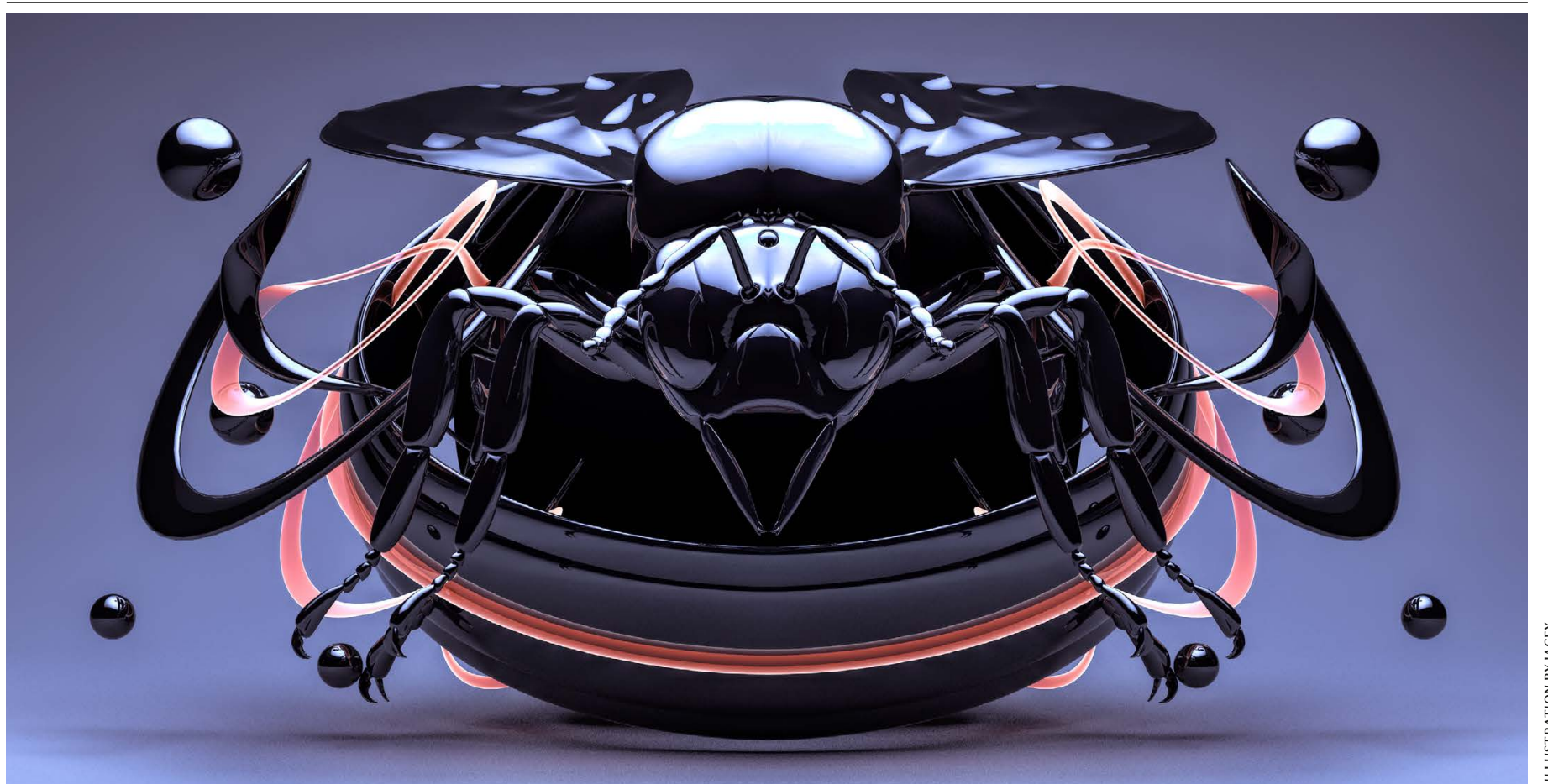

$W$ hen I left for the first time, there were tears in your eyes, and you grasped my hand with a quiet, desperate affection.

"It's only a year," I whispered, words lost to the song of idling stardrives, the clatter of shuttle lifts and the din of the spaceport swallowing our goodbyes like the singularity I was bound for. All around us, hundreds of pairs and trios spoke the same words in mirrored farewell, black uniforms crisp and stiff and unchallenged, the fabric gripping my skin the only thing fresher than I was.

"I'll be back before you know it," I told you, even though we both knew that was a lie. Even though we both knew I couldn't promise I'd come back, and you couldn't promise you'd wait that long. "It's only been skirmishes and scouting parties."

"I love you," you replied. The first time you said it, the stubble on your face stretched like a constellation as your dark lips curled into a smile.

"I love you, too." The second lie I told you that day. Not the first part, and not because I didn't mean it, but because I knew I could never mean it the same way you did.

$* * * * *$

The next time I left, there was a ring on the chain around your neck, and chevrons on my shoulder matching its silver. I didn't promise, that time, that I'd be back soon, because we both knew there was no end date to the assignment. I didn't promise you that l'd be back at all, because the scars on my face screamed how close the previous time was.

The crowd around us was even thicker, and their faces all looked so young. I hadn't told you everything about the first strike or the sallies. Hadn't described how it felt to watch your friends die beside you, how it breaks you to make peace with the fact you're about to do the same. Then, how it breaks you again, even worse, when you realize you alone among so many will survive. But even you knew more about what we were facing than the new recruits did. At least you'd heard me scream and seen me shake in my sleep, a more honest advertisement than the recruitment sims.

There were fewer tears that time, just a glistening in your grey eyes. Eyes that used to remind me of stars, back when the night sky was a thing to be longed for, not feared.

"Be safe," you whispered, and I simply nodded. There was no point in lying when the truth was so clear.

$* * * * *$

This time, the platform is nearly empty, just you and me and the two tiny forms beside you. There are no tears, your eyes long-practised at desert goodbyes, the only star to be seen the silver one on my chest.

I feared you might leave when I told you I was going, and I mumbled on about words like duty and honour, how the fate of this system was more important than the happiness of two people. And each time a sad smile stretched across your face, because you knew the truth even before I did.

I was never a good partner. I was an even worse parent. But in the space between stars, with a gun in my hand, I had finally found a thing I excelled at. I never believed in a god, not the way that you do, but if she ever existed, it was clear she designed me for this. And I knew 


\section{Futures}

that I should feel guilty for that, even more so because I felt no guilt at all, so you nodded and agreed, and told me I was strong, even though it was you who carried the weight of us both.

Your arms grip me in a knowing embrace. We could lie again this time, like we did when we were still children, that I'll be coming back, but there's a reason no one else is on this platform with us.

When a bee leaves the hive to sting a bear, it has no illusions it will survive the encounter. It simply hopes that if it can inflict enough pain, it might convince the beast to choose a less troublesome target.

This time, I see the words begin to form on your lips, and I'm terrified that you will finally ask, because for the first time, I truly want to say yes. But after a moment, grey eyes like the metal behind me, you shut your mouth and force a smile.
“Be brave," you whisper, and I love you for that, because if you asked me to stay, I'm afraid that I would.

Steven Fischer is a resident physician in the Pacific Northwest of the United States. You can read more of his work at www.stevenbfischer. com or follow him on Twitter @stevenfischersf. 